\title{
“THE NARRATIVE IS AMBIGUOUS AND THAT LOCATION ISN'T THE RIGHT LOCATION": PRESENTING AND INTERPRETING MEDIEVAL SAINTS TODAY IN CANTERBURY, DURHAM AND YORK
}

\author{
TIINA SEPP \\ PhD, Research Fellow \\ Department of Estonian and Comparative Folklore \\ Institute for Cultural Research and Fine Arts \\ University of Tartu \\ Ülikooli 18, 50090 Tartu, Estonia \\ e-mail: tiina.sepp@ut.ee
}

\begin{abstract}
Drawing on research for the Pilgrimage and England's Cathedrals, Past and Present project, this article explores how the project's medieval case study cathedrals Canterbury, Durham and York - present their saints and shrines, and how visitors react to and interpret them. While looking at various narratives - predominantly about saints in historical and contemporary contexts - attached to these cathedrals, I also aim to offer some glimpses into how people interact with and relate to space. I argue that beliefs and narratives about saints play a significant role in the pilgrimage culture of the cathedral. I will also explore how the lack of a clear central narrative about the saint leaves a vacancy that will be filled with various other narratives.
\end{abstract}

KEYWORDS: saints $\bullet$ cathedrals $\bullet$ pilgrimage $\bullet$ Canterbury $\bullet$ Durham $\bullet$ York

\section{N T RODUCTION}

This article* will explore how three medieval cathedrals - Canterbury, Durham and York - present their saints and shrines, and how visitors react to and interpret them.

* This research was supported by the Arts and Humanities Research Council (grant number AH/ L015005/1). The article is based on research conducted between 2014 and 2018 for the Pilgrimage and England's Cathedrals, Past and Present interdisciplinary research project. The project carried out research within four English cathedrals, three of them Anglican and predominantly medieval (Canterbury, York Minster, and Durham), and one Roman Catholic and modern (Westminster). Analysis of the resident saint of Westminster Cathedral - Saint John Southworth is not included in this article because neither the saint nor the cathedral are medieval. For more about Westminster Cathedral, see, for example, Bowman et al. 2018 and Jenkins and Harris 2018. 
In the Middle Ages, the cult of relics was one of the most characteristic features of Western Christianity, and saints were the focal points of pilgrimages. With the changes in theology brought about by the Reformation, shrines were demolished and lots of saints were simply forgotten about. Today, with the revival of interest in pilgrimage and cathedrals, saints have once again started to appear in the foreground. I will look at legends, rumours and stories about medieval saints as expressions and shapers of vernacular religion and explore what impact they have on the pilgrimage culture of the cathedrals.

As huge buildings that often dominate the profiles of both cities and religious denominations, cathedrals "combine the spiritual with the spectacular" (Coleman et al. 2019: 241). While writing of cathedrals, the sociologist Grace Davie (2012: 486) noted:

In the 1970s, these iconic buildings were frequently referred to as dinosaurs - with the strong implication that they were excessively large and increasingly useless. Currently the evidence tells us that they are growing both in terms of their regular and less regular worshippers, and in terms of their more transient communities of pilgrims and tourists.

Since the mid-1990s visitor numbers as well as numbers attending cathedral services have grown significantly and the most popular cathedrals have been those that are both medieval and larger in scale (Curtis 2016: 2-4). Cathedrals are multivalent places: they are regarded as heritage sites by some, as sacred destinations by others, and as both simultaneously, thus attracting people from varied cultural backgrounds and religious affiliations, including those of 'no religion'. John Eade and Michael J. Sallnow (2000: 15) have noted that major shrines and pilgrimage sites have the "capacity to absorb and reflect a multiplicity of religious discourses, to be able to offer a variety of clients what each of them desires". When discussing forms of Anglican reflexivity, Simon Coleman (2018: 36) has recently remarked that

There is the assumption - or hope - that an inherent spirituality may be immanent within the apparently secular assumptions and practices of the publics who now willingly enter their doors in such great numbers. In this sense, the special capacity of cathedrals to bring together cultural and spiritual capital under the same fan-vaulted roof is a matter of anticipation as well as ambivalence: it is a form of 'impurity' and adjacency that has the potential to be highly productive.

I am going to look into some of the belief statements and stories told about our case study cathedrals, focusing on how people's ideas, beliefs and worldviews are expressed through narratives. Marion Bowman and Ülo Valk (2012: 7-8) point out that belief seems to be an elusive category, however, "understanding becomes easier if we look at expressions of belief in behaviour, ritual, custom, art and music, in textual and other forms". When analysing belief as generic practice, Valk (2012: 351) notes that

[m]any beliefs are unstable and inconsistent, their contents cannot always be univocally fixed and their articulations take multiple forms, therefore approaching them through the paradigm of genre offers effective conceptual tools with which to see unity in their seemingly endless variation. 
Narrative is of great significance in relation to pilgrimage. Jill Dubisch (1995: 126) has commented: "There is a large oral tradition, consisting of pilgrims' own experiences and those relayed to them by word of mouth, a large part of which is not found in the literature of the church". In this article I am going to present and contextualise various legends, so the genre of legend is of great significance. Legends are generally defined as belief narratives: stories that present arguments about the supernatural (Dégh 2001; Oring 2008; Valk 2012). The discourse of disbelief forms a significant part of any debate about belief. As Linda Dégh (2001: 97) puts it:

The legend is a legend once it entertains debate about belief. Short or long, complete or rudimentary, local or global, supernatural, horrible, mysterious, or grotesque, about one's own or someone else's experience, the sounding of contrary opinions is what makes a legend a legend.

It is also important to note that scholars of folklore view religious expressions from the 'bottom up' viewpoint. My research has been carried out in the broad framework of vernacular religion, as defined by Leonard Norman Primiano (1995; 2012). He comments:

Vernacular religious theory understands religion as the continuous art of individual interpretation and negotiation of any number of influential sources. All religion is both subtly and vibrantly marked by continuous interpretation even after it has been reified in expressive or structured forms. (Primiano 2012: 384)

\section{THE IMPORTANCE OF HAVING A SAINT}

The writer and long-term resident of Canterbury, Lois Lang-Sims (1979: 3), has poignantly described how people felt about the saints in times of despair: "During the Second World War fifteen high explosive bombs fell in the Precincts, and the Cathedral itself was not hit. In the highly charged atmosphere of that time, many people believed that its saints had been protecting it."

The cult of saints permeated medieval society. It is perhaps not surprising that the revival of interest in pilgrimage and cathedrals has led to renewed interest in shrines and saints (see, for example, Tavinor 2016). John Jenkins (2018) has noted that there is a tendency among both cathedral staff and the visiting public to see medieval pilgrimage as a 'golden era' where people came to cathedrals for all the right reasons and had the right experience; yet the 'Benedictine welcome' at Durham Cathedral, for example, consisted of the exclusion of women from the church from the Conquest to the Reformation. Medievalism - interest in and nostalgia for the Middle Ages - plays a huge role in the increasing popularity of saints and cathedrals. It seems that many people want to immerse themselves, at least temporarily, in the Middle Ages. Umberto Eco (1986: 65) has suggested that people started dreaming of the Middle Ages from the very beginning of the modern era. Describing the development of the Walsingham pilgrimage, Coleman (2009: 23) brings out the important role of mimesis as a form of revival of the past. When asked to reflect on the revival of interest in pilgrimage and cathedrals, a Canterbury volunteer commented: 
And I wonder if it's really taking us back to more of the medieval mind, the medieval way of thinking that everything's connected: the architecture, walking, worship, experiencing God, looking at the stars. All those things are part of a greater whole. [...] I think it is a desire to maybe understand things in the way that the medievals understood things. Because the idea of a cathedral as this completely beautiful, meaningful, mathematical structure that acts as a container for people to encounter the divine through ritual and worship, is just something so beautiful and wonderful and maybe we lost sight of it with the Reformation and then capitalism. (Interview: November 26, 2014)

In the Middle Ages, saints were the focal points of pilgrimages. According to Graham Jones (2007: 9), "Devotion to purposefully chosen patron saints is a cultural marker with significant potential for the better understanding of historic landscapes and individual communities." Patron saints, relics, church buildings and devotional practices had an important effect on communal coherence and local identities (Katajala-Peltomaa et al. 2016: 11). Eamon Duffy (2004: 43) notes that the presence of the body of the saint within the community acted as a bonding agent. Their relics became the focus of festivals and were carried out into the streets and fields to bless them or to avert disaster; the rhythm of the sanctoral calendar brought visitors from far off to the community, and was a source of pride and prestige (ibid.). Jones (2007: 17-18) comments:

Access to the saint's body was hugely beneficial. Medieval illustrations show pilgrims crawling through the apertures in the sides of shrines. Saints' tombs were often provided with barred windows through which sticks could be poked so that rags tied to the ends could ingest sacred energy. There was biblical precedence for this belief: 'Who touched me?' asked Jesus, feeling 'power flow out from him' as an 'unclean' woman grasped at his robe.

Jenkins (2018) has pointed out that it was in the cathedral's interest, to a certain extent, to promote their saint's shrine as a source of revenue and prestige as a pilgrim destination, yet it was against the cathedral's interests as a functioning monastery or - in the non-monastic ones - a site of corporate worship, for the access to its holy spaces to be unconditional.

With the changes in theology brought about by the Reformation - which ended cathedral pilgrimage in England - lots of shrines were destroyed. As Duffy (2004: 47) succinctly put it, "[t]he Protestant reformers worried that the celebration of the saints diminished the work of God, and believed that the saints were the rivals of Jesus". Today, with the revival of interest in pilgrimage and cathedrals, saints have once again started to appear in the foreground. The nature of interest in the saints has of course evolved with time. While the medieval pilgrims were usually after a hands-on, healing experience, contemporary ones tend to be attracted by the idea of a saintly person. In recent years there has been a trend in Anglican cathedrals to restore shrines and bring saints back into the limelight, so much so that some scholars have started to talk about 'shrine envy' with regard to cathedrals. However, attitudes to saints can vary widely even among the staff and visitors of one and the same cathedral. This is perhaps not surprising, given that there has always been a "fundamental ambivalence" in the cult of the saints (Duffy 2004: 39). 
The renewed popularity of saints and shrines seems to have brought with it the need for new narratives. In the following sections I will look at how our case study cathedrals present their saints and how people react to them.

\section{CANTERBURY CATHEDRAL AND THOMAS BECKET}

Canterbury Cathedral was a major pilgrimage centre in medieval England and large areas of the building were shaped by the cult of St Thomas Becket. It was through the martyrdom of Thomas Becket that Canterbury Cathedral became a place of pilgrimage. ${ }^{1}$ On the night of December 29, 1170, shortly after the end of Vespers, Archbishop Becket was chased into the north transept of his Cathedral and slaughtered by the four knights. These knights had witnessed King Henry's angry outburst at the archbishop for frustrating the King's ambitions to bring the liberties of the English Church under greater royal control. While the knights probably set out aiming to arrest the archbishop, on their arrival Becket first resisted and then proceeded to provoke them, leading to the most shocking and notorious murder of the Middle Ages (Duggan 2004: 201-223; Jenkins 2018). Then, as John Adair (1978: 39) poetically put it, "Within days of the martyrdom of St Thomas pilgrims from the towns and countryside near Canterbury began to converge on the cathedral, the first streams which swelled into a mighty river of pilgrims".

Miracles were reported within a fortnight of his murder on the steps of his altar during mass, and dedications proliferated (Jones 2007: 31). Jenkins (2018: 4) notes that the immediate response of the congregation within Canterbury Cathedral to the death of their archbishop was to gather his blood in receptacles or to soak it up with scraps of cloth and carry it away as a relic. The first miracle was probably performed later that night, not under the auspices of the monks but in a citizen's house where a woman was cured by drinking a tincture of Becket's blood (ibid.). Duffy (forthcoming) has pointed out that

Thomas was unique in his threefold claims to sanctity - as martyr for the liberties of the Church, as convert from an extravagant secular career to an austerely ascetical life as holy bishop, and, not least, as an exceptionally prolific thaumaturge (more than 700 miracles were attributed to him by the time of his canonisation in 1173).

Becket continues to play a huge role in attracting people to Canterbury today. A large number of Roman Catholic visitors would come because of the martyrdom of Becket; for Anglicans there is the additional attraction of Canterbury Cathedral being the mother church of the Anglican Communion and the seat of the Archbishop; many would come because of Chaucer's Canterbury Tales (1392) and Thomas Stearns Eliot's Murder in the Cathedral (1952). Will Durant (1957: 50) has said that "Chaucer created an innful of characters so heterogeneously real that they seem truer to English life than the stuffed figures of history". The role of Murder in the Cathedral and Canterbury Tales in perpetuating the fame of Canterbury Cathedral and its place in the pilgrimage culture cannot be overestimated - they and numerous other stories and legends about Becket keep the memory of Thomas Becket alive. 
While the majority of contemporary Cathedral visitors may not be drawn to Canterbury with the aim of venerating Becket, the story of his martyrdom remains a main attraction. Tour guides usually follow the 'Becket route' - the places inside the Cathedral associated with him, such as the site of his martyrdom, the site of his first tomb in the eastern crypt, the Trinity Chapel where his shrine once stood, and the Miracle windows. In the Middle Ages, the four cultic sites had been the martyrdom, tomb in the crypt, a small Corona chapel (where Thomas' head relic was displayed) and shrine (Jenkins 2018: 7). However, Jenkins (ibid.) argues that these did not form a pilgrim route as is commonly believed.

It is interesting to note that the Corona chapel in the east end of the Cathedral, which housed a head reliquary with the piece of Becket's skull that had been hacked off by the knights, is now dedicated to the saints and martyrs of our own time, demonstrating that the idea of saints still resonates. The guided tours of the Cathedral obviously differ according to the preferences of the person giving them. Some of the tour guides would stand the group in the corner of the Martyrdom chapel and give a detailed overview of Becket's death, including the bit about one of the knights spreading Becket's brains on the floor with his sword. Sometimes the visitors are asked to identify the four swords in the sculpture above the Altar of the Sword-Point, commemorating St Thomas Becket's death (clue: two are formed by the shadows). Some guides like to mention the hair shirts that Becket was wearing, and that after his death they were found to be full of lice and other insects, and his body was covered with bug bites. That would show that only the soul matters, not the body, explained one of the guides.

Huge numbers of people want to see where Becket was killed and where his shrine stood; some want to pray and light a candle ${ }^{2}$ in the Martyrdom. According to the Cathedral staff and volunteers, two most frequently asked questions by visitors are, "Where was Becket murdered?" and, "Where are the toilets?" One of the volunteer guides told us:

Nearly every time you go on duty [...] somebody wants to know something about the Becket story [...] Where, why... you know, people don't understand the reason why. Then I had one lady say to me, when I was explaining, "Henry II ordered him killed", and I said, "No, actually, he didn't order him..." I was going on to say that he had a temper and that sort of thing; she said, "Yes, he did! I know he did! I saw the film!" Most people have remembered from school, if they've remembered nothing else other than 1066, the murder in the Cathedral, they've remembered that; and they may not know the whole history behind it [...] but they're very interested in where you show them the door that the knights came through; and the "Why did he get murdered? What happened? What was the argument?" this sort of thing. (Interview: November 21, 2014)

Another volunteer expressed his ambiguous feelings about the fascination with Becket's death displayed by some of the visitors:

I think there are two clearly defined areas that are of immense attraction to the cathedral. [...] The number one attraction is usually - where was Becket murdered? People want to see the place. Sometimes they even have a secondary question, where is he buried? But the main one, yes, they want to see the spot where he was murdered. Now for what reasons I don't know. [...] Why do you actually want to see the spot where a human being was decapitated practically and his brains 
spread all on the floor? What appeals to you? That's a morbid thing to do. There are much more beautiful things and nice things about the cathedral. [...] But I suppose the simple answer is that Becket is so famous that it's like fulfilling a desire in you to see just where it all happened. [...] And of course when you have somebody like Becket who is a foremost saint, people have a great love. Even when I talk to people they know very little about Thomas Becket but they all have one thing in common they can identify him as a man who had great belief in his god to the degree that he would even die. That seems to ring true still on its own with many, many people who are non-believers that somebody believes enough in his religious god that he would die and even would deny the power of the king. [...] So, to do that still impresses a lot of people and they come and want to see just where this man was killed. (Interview: November 19, 2014)

Becket's dominant position in the cathedral narrative is, however, challenged by some who think that other saints have unfairly been left in his shadow. For example, some people have said that there was "too much of Becket" and "he was here only for five minutes and was not a very saintly figure." Some suggested that it was only thanks to the brutality of Becket's murder that pilgrims started to come and bring in the money. For some, St Dunstan (a 10th century Archbishop) is equally important - but since unlike Becket St Dunstan lived to an old age and died peacefully surrounded by fellow monks, he is now almost forgotten. Duffy (2004: 40) has pointed out that saint and hero sometimes merge, and in many saints their courage and sheer sanctified bloodymindedness are hard to distinguish. Some people we spoke with were not convinced by the narrative of Becket's "resolute stand against royal encroachments on the liberties of the Church" (Duffy 2002: 144) and expressed their doubts and ambiguous feelings about Becket. One pilgrim commented, "I am not clear what to think of Thomas Becket, was he really a saint or was he an administrator of his king; who was he? I hope you will help me to find it out." (Interview: August 13, 2015). Another pilgrim told us:

Now I've more background information to have a little more detailed image. Not only just, oh, a martyr, who died defending the church or whatever. I think it's complex, it's something to do with power and politics, this whole story. And it looks to me he was also a little stubborn. And he created himself many problems which weren't really necessary. But on the other hand, Henry seemed to be similar in this area. (Interview: November 25, 2014)

In the words of a member of staff: "We started with Augustine, and only after that Thomas Becket. The Cathedral is bigger than Thomas Becket. And of course he is a huge part but St Augustine, who established Christianity here; arguably he's more important than Thomas Becket." (Interview: August 13, 2015)

Many visitors are surprised and some are even sad to hear that Becket's remains are no longer in the Cathedral. In the Trinity Chapel, where there was once a magnificent shrine to Becket, there is now empty space with a lit candle marking the shrine. At the Dissolution - in the year 1538 - Becket's shrine was demolished and his relics removed and burned; Henry VIII proclaimed the victor over Henry II to have been no real saint (Durant 1957: 567). However, what really happened to Becket's bones and where they are now is a topic that many people like to speculate about. Alternative interpretations of what happened to the bones of Becket have captured people's imagination for centu- 
ries. John Butler's fascinating book The Quest for Becket's Bones: The Mystery of the Relics of St Thomas of Canterbury (1995) offers a good overview of various hypotheses about the final resting place of Becket's bones. Were they really burned and the ashes scattered in the year 1538, as the official history goes? Or, given that Henry VIII's commissioners did not arrive unannounced, did the monks surreptitiously remove the saint's remains to a safe place and place somebody else's remains at the shrine? If this was the case, where did they hide the relics and where are they now? During my field trips to Canterbury, this topic did crop up every now and then.

One might ask if and why it really matters what happened to the bones of Becket. How would it affect the life of the Cathedral if Becket's bones were indeed found and identified? As soon as I started doing fieldwork in Canterbury, I was told that some people know where Becket's bones are but they are not allowed to say. Some are convinced that only the dean knows the whereabouts of the chest with the relics, and this knowledge is passed on from one dean to the next one. One visitor showed me a sarcophagus where he believed Becket's remains to be. Some people would argue that all this 'bones business' is irrelevant. For example, the Cathedral staff prefer to tell the ageless story of Becket and the moral issues which fits in very well with the ethos of the Cathedral. A former resident of Canterbury asked: "What happened to the bones of Thomas Becket? [...] If Becket's bones were found in Canterbury Cathedral, would that make it place of pilgrimage for Catholics to go [...] or is it preferable that they are not discovered?" (Interview: November 27, 2014) These sentiments were echoed in some other interviews with senior members of Cathedral staff and volunteer guides. As a Cathedral worker put it to us:

If suddenly you had the real bones of Becket restored to you, you're going to be a museum, a tourist attraction, a theme park. And I think that could be managed. But to be honest, it's so big and alarming we'd rather it stayed as it was. [...] I don't think anybody's really keen to find the bones of Becket. I think mystery serves us better than actuality. Because what would happen if we had all the money in the world but the cathedral is being worn to shreds by the feet of passing pilgrims and you would have to knock down a couple of houses in order to get the flows to come through. (Interview: November 28, 2014)

He is here expressing the fear that if the relics were to be found, the Cathedral might come to be primarily associated with them; they prefer to promote the ageless story of Becket's bravery, instead. A volunteer guide told us the following:

Do you know, I prefer that. I suppose it's because of my nonconformist background, because I'm not into all this going to relics and things like that, I just, I love the fact that there's a simplicity of that candle there. And also, I don't want people to come here to sort of [...] bowing down to this, you know, to this man who, okay, he was made a saint because he was killed here, but in actual fact he wasn't around for long, was he? He was an archbishop for eight years and he was only in Canterbury for two of them. You know, so, to me he's not so special. He's only special because he actually got murdered I suppose really... [...] So, you know, I wouldn't like it if people were climbing up those stairs on their knees and bowing down in front of that altar. (Interview: November 7, 2014) 
Even though the destiny of Becket's bones remains unknown, rumours and speculation abound. With regard to the 'official' truth versus vernacular theorising about the remains of a saint, I could not help noticing a parallel with the Santiago/Priscillian debate. Several people believe that the remains kept in the cathedral of Santiago de Compostela do not really belong to St James but to Priscillian, the charismatic bishop of Avila, who was accused of witchcraft and heresy and tortured and beheaded in 385 (Ferreiro 2000; Sánchez Dragó 2004; Sepp 2014: 29). In both cases there is a widespread belief that there are some people who know the truth about the relics but prefer to keep it from the general public. We can see a parallel here with the Middle Ages, when monks of Canterbury carefully curated the shape of, and access to, the cult within the Cathedral in order to confirm their role as sole custodians (see Jenkins 2018). Despite the different views and interpretations of Becket's saintliness - or perhaps because of them - the story of his martyrdom remains a major attraction of Canterbury Cathedral, and the dubious destiny of his remains fuels a wide range of speculations and vernacular theories.

\section{DURHAM CATHEDRAL AND ST CUTHBERT AND THE VENERABLE BEDE}

While Canterbury is first and foremost known for the martyrdom of Becket, Durham Cathedral can boast two famous saints - St Cuthbert and the Venerable Bede. I have noticed that the saints of Northumbria are still a live part of the culture - anywhere in County Durham you will find people who know who Cuthbert, Bede, Oswald, Aidan, and Hild were. Jones (2007: 154) has noted that few dedications excite more local interest than those commemorating saints of Anglo-Saxon England, and that regional identity seems an obvious motive in the promotion of many of these cults.

The destination of many pilgrims to Durham is the shrine of St Cuthbert, the 7th century monk and bishop of Lindisfarne. In the Middle Ages, pilgrims from all over England and northern Europe would have travelled to Durham to venerate him. As a prior of both Melrose Abbey (now in Scotland) and later of Lindisfarne, St Cuthbert was spreading Christianity in the north of England. In 875, to escape the Danish raiders, the Lindisfarne monks fled with the relics of Saint Cuthbert (and the head of St Oswald which ended up in Cuthbert's tomb) spending time at Chester-le-Street and Ripon, before finally arriving in Durham in 995. It is claimed that Cuthbert's remains became the greatest focus of pilgrimage in early medieval England until the death of Becket in 1170. Although St Cuthbert's magnificent shrine was destroyed at the Reformation, his relics are still in the raised Feretory - a stone platform behind the High Altar - constructed for it. The Venerable Bede, who was St Cuthbert's most famous hagiographer, portrays him as a kind and humble man, also one who had a special relationship with creatures of the natural world. Bede (2013 [1939]: 189-191) describes how otters warmed and dried Cuthbert's feet after he had spent the night praying in the sea:

Now, according to his custom, while the others were resting at night, he would go out alone to pray, and after watching long throughout the dead of night, he would return home just at the hour of common worship; and on a certain night one of the 
brethren of the same monastery, seeing him go silently out, followed in his footsteps secretly, seeking to discover whither he meant to go and what he intended to do. Cuthbert left the monastery with the spy following him and went down to the sea, above whose shores the monastery was built; going into the deep water until the swelling waves rose as far as his neck and arms, he spent the dark hours of the night watching and singing praises to the sound of the waves. When daybreak was at hand, he went up on to the land and began to pray once more, kneeling on the shore. While he was doing this, there came forth from the depths of the sea two four-footed creatures which are commonly called otters. These, prostrate before him on the sand, began to warm his feet with their breath and sought to dry him with their fur, and when they had finished their ministrations they received his blessing and slipped away into their native waters. He forthwith returned home and sang the canonical hymns with the brethren at the appointed hour.

Cuthbert continues to be popular today. This can be seen in the numbers of people who come to the shrine prayers, ${ }^{3}$ light a candle, or leave a written prayer for someone who has died or has health problems. Many people just 'drop in to say hello' to Cuthbert and sit at his shrine. A volunteer steward told us, "I always go and say 'hello' to St Cuthbert. One can be guaranteed a quiet space at the tomb". (FM: May 2015) St Cuthbert's feast day is on March 20 and around that time St Cuthbert's festival is celebrated at Durham Cathedral every year. There are several events and special services, for example, St Cuthbert's day walk and procession from Chester-Le-Street to Durham. The participants take the route which the monks were believed to have used when carrying St Cuthbert's remains to Durham Cathedral, his final resting place. Another special service is that of the Founders and Benefactors. At the end of both this and the Cuthbert's day service all process down the North Quire aisle, then the clergy go into the Feretory - the Cathedral Chapter kneel around the shrine - and the congregation goes all round the Nine Altars. All these events are very well attended, indicating the continuing drawing power of Cuthbert. With regard to Cuthbert's cult, it is important to highlight his long-standing regional status, so much so that in medieval times the people of the north east were called haliwerfolc - the people of the saint. The relationship of Durham Cathedral to the city and the region is unique. The sense of personal connection with St Cuthbert has been a powerful force through the centuries and remains so today. Several guides and stewards proudly tell the story of "Saint Cuthbert's mist", which is believed to have saved Durham from being bombed one summer night in 1943 . The Luftwaffe had aimed to bomb the Durham Viaduct, and this would have meant destroying the city and the Cathedral. As the plane approached, a mysterious mist came out of nowhere and descended over the city, hiding every building. The city was saved from bombing, and the mist has become known as Saint Cuthbert's mist. Whilst telling the story the guides point at the Royal Air Force window in the north-west corner of the Cathedral's nave. The sentiment of being 'Cuthbert's people' continues to be strong in County Durham. A County Durham resident noted: "I'm a north eastern lad, St Cuthbert has always been - I've always been aware of his story and his life and the Holy Island Lindisfarne, special place for us all, including me". (Interview: June 26, 2016). A bedesman, who was born in Chester-le-Street in County Durham, told me, "We are Cuthbert's men" (FM: May 2015). 
It seems that people in Durham can be quite protective of their saints. For example, in Canterbury there is a pub called The Thomas Becket; in Durham there is no Cuthbert Inn or similar. Is it just a coincidence or would naming a pub after St Cuthbert be a sacrilege, as one visitor suggested? She told me, "People think of Becket as a man and Cuthbert as a saint. Becket was a bishop who was murdered in the cathedral. Cuthbert was a saint." A volunteer overhearing our conversation said he would love a pub called St Cuthbert's Arms or similar, and added that Cuthbert would have been a good customer. (FM: May 2015)

As opposed to Canterbury where the relics of Becket are long gone, St Cuthbert's are still present in his shrine at Durham Cathedral. We asked a canon of Durham how significant this fact was for him, and he said:

I think for me, and this is possibly partly because of my background, stuff like relics is not a big deal for me. Yes, we do have Cuthbert's remains here but Cuthbert is not here in a tomb. Cuthbert is here in the building, in the ethos. In a sense you know that you are one of Cuthbert's disciples and that's what's important I think rather than the fact that his body is in the hole in the ground, and his cloak is in the treasures, and his pectoral cross and all the rest of it. Yeah, that's great. But for me it's the spirit of Cuthbert, and I don't mean that in a sort of spooky sense. I mean everything that Cuthbert stood for, everything that the pilgrimage was important for me, you know, [to] have taken the good news of Jesus to the ordinary people of the North-East. And that's I think what's enshrined in the cathedral. (Interview: May 26, 2015)

This echoes the views expressed by some of the workers of Canterbury Cathedral, who said they were quite happy with the candle symbolising the shrine. At the same time, legends about St Cuthbert's incorrupt body continue to circulate and to many people they are the main evidence of his sainthood. Below is one of the recounts of the legend (based on The Rites of Durham):

One day, in the late 1530s, it was Durham's turn to be the object of a visit from Henry VIII's commissioners, including the greatly feared Dr Lee. [...] They brought with them a goldsmith, who, when he had taken off the gold and silver and precious stones, came to a chest strongly bound in iron. The goldsmith took a smith's great hammer and smashed open the chest. He found Cuthbert 'lying whole with his face bare and his beard as if it had been a fortnight's growth.' [...] Then Dr Henley came up and 'handled him' and saw that he was indeed whole and undecayed. [...] The visitors then commanded the monks to take him to the vestry where he could be kept safely until the King decided what should be done. (Groves 2008: 5)

St Cuthbert is not the only saint to whom Durham Cathedral is the final resting place: the Cathedral also holds the remains of the Venerable Bede - the 7th century monk of Jarrow and the greatest of the Anglo-Saxon scholars. Bede's most famous work is Historia Ecclesiastica Gentis Anglorum ('The Ecclesiastical History of the English People') which was completed in 731 AD. Bede dedicated to Cuthbert not one but two Lives - in verse and in prose. Bede's History and his prose Life of Cuthbert were widely read works and spread knowledge of these English saints across the continent of Europe (Bartlett 2013: 48-49). Bede's tomb was set up in the Galilee Chapel at the Cathedral's western 
end from 1370; it was a quiet area where both men and women could stay in supplication at the tomb (Jenkins 2018). When we asked a guide what her favourite area of the Cathedral was, she said:

Apart from Cuthbert's shrine, which of course is the central part of the Cathedral, it's the Galilee Chapel. For all sorts of reasons. One, I love the architecture. I think it's such a wonderful contrast to the hugeness of the Romanesque. For another reason, women could go there. Another reason is it's got some of the most beautiful ancient works of art and the most beautiful modern works of art. And the final reason is because Bede is buried there and Bede is my great hero. I always tell anybody who teaches, lectures, studies - he should be your patron saint. He said, "My chief delight has been to teach and to study". (Interview: May 25, 2015)

In reply to our question about lighting a candle in the Cathedral, one visitor said, "I did, funnily enough, as a mark of respect for Bede. Us historians have to look out for each other!" (Interview: November 2, 2015). A local resident of Durham commented:

And so the cathedral essentially is the cathedral that grew out of St Cuthbert's sainthood. I can respect him for that, and realise he was a great and godly man, but Bede means a great deal more to me I think, because he was a scholar [...] And it is said that although he only had one or two books, he became the finest scholar in Western Europe, and so he is my favourite! He is the one that means something to me, not because he is a saint, but because he was a scholar who also loved God and worshipped God and gave his life to God. (Interview: January 27, 2017)

St Cuthbert has always overshadowed Bede (and other saints) within the Cathedral and the region. For example, takings from the shrines show that women restricted to the Galilee Chapel preferred to give money at the altar of the Holy Cross, where there was a surrogate shrine to St Cuthbert, rather than to the bodily-present Bede (Jenkins 2018). Cuthbert's dominant position in the cathedral narrative today is challenged by some who think that Bede has unfairly been left in his shadow. They believe that the only important thing in Durham Cathedral is Bede's tomb. A retired miner from County Durham, who goes to the Cathedral every month, told me,

Cuthbert doesn't really mean anything to me. I'm not even sure he was a saint. I think the story about his incorrupt body is a myth; also, he wasn't from here. Bede is different though, I would say he is a north-eastern icon. (FM: December 2018)

Some people have suggested that Cuthbert was a misanthropic hermit who did not have the same influence on people's lives as Bede. As a patron saint of scholars and students, Bede is also known internationally: many people both inside and outside the UK know of Bede but do not necessarily know that he is buried in Durham Cathedral. Speaking of particular spots that visitors seem to be attracted to, a Durham Cathedral worker told us the following:

I think Cuthbert's shrine is the biggie. And it always intrigues me that it's Cuthbert, not Bede, and I've pondered whether that is just because of who Cuthbert is in the popular psyche or whether it's something to do with the architecture as well. The fact that it's in an enclosed space, up steps, East End, as opposed to Bede being in a more public space, tucked in one corner of a more public space. And also Bede 
not being quite as well known, although perhaps ought to be. But I'm just wondering how much it's Cuthbert because it's Cuthbert and how much is architectural because of the space ... I think it is probably a bit of both. (Interview: May 27, 2015)

With regard to how the two saints relate to each other - Bede wrote a Life of Cuthbert and how they can be seen in dialogue with each other, Coleman has suggested thinking of them in relation, touching on each other's lives:

Yes, Cuthbert is dominant, but Bede has potential, not as a challenger of Cuthbert, but to enhance his story and make us think about how Bede himself created narratives - was a creator of history and of stories. Also, while Cuthbert's story can actually be used as a boundary-challenging narrative, celebrating the north-east but also uniting England and Scotland, Bede can be seen as a figure showing how the history of England need not be written through the concerns of the south of England alone. (Coleman 2017, personal communication)

Arguably, the cathedral's architecture and the tombs' locations as well as various, sometimes contradictory, narratives have a direct impact on how Bede and Cuthbert are perceived and interacted with, but both act as a point of focus for visitors.

\section{YORK MINSTER AND ST WILLIAM OF YORK}

While Becket and St Cuthbert are household names in Canterbury and Durham cathedrals respectively, St William of York does not seem to enjoy similar fame and popularity. The overwhelming majority of people visiting York Minster have never heard of their resident saint - St William of York, a 12th century archbishop who was allegedly poisoned during a mass. When I first went to York Minster in September 2014, I was moved to see these words written on the plaque marking St William's tomb in the middle of the carved pillars of the Norman crypt: "Remember St William of York and all pilgrims". At some point in spring 2015 the plaque disappeared and none of the staff or volunteers seemed to know what had happened to it. It almost felt as if William of York had become so insignificant that he did not deserve even a plaque with his name next to his tomb. For health and safety reasons, the tour guides are not supposed to take groups down to the crypt; for a variety of reasons the flower arrangers usually ignore the crypt, and all that St William can get is occasional leftovers. ${ }^{4}$ Most visitors to York Minster have never heard of the Minster's resident saint, who according to Christopher Norton is "one of the most obscure saints of medieval England" (Norton 2006: 1). A volunteer guide and chaplain told us, "Most people don't realise that there's a saint here. They are not surprised that there is a saint but they don't usually come thinking they are going to see St William." (Interview: December 16, 2015). I have noticed that when talking about St William, some of the staff and volunteers of the Minster sound almost embarrassed about him. As one staff member of York Minster put it to us:

People are a bit uncomfortable about St William. [...] I think that even amongst the clergy there is a sort of feeling that he's perhaps a bit less legitimate than other saints. And I think there is this slight awkwardness about him, which is why he isn't known to everyone. I never knew of St William till I started working here. (Interview: February 23, 2015) 
Norton (2006: 1) comments that "Even in the city whose name he bears he is less well known than his younger contemporaries Aelred of Rievaulx and Thomas Becket".

So, who is William of York, a saint whose remains are kept in a stone coffin, a recycled Roman sarcophagus tucked away in the western crypt of York Minster? William Fitzherbert managed to be Archbishop of York not once but twice. When he came back to York to take up archbishopric for the second time, he rode over the old Roman wooden bridge on the River Ouse. The bridge was so packed with spectators and supporters that it collapsed and everybody fell into the water. William started to pray and the miracle is that nobody died. Norton (2006: 1) calls it "one of the least remarkable miracles in the annals of hagiography". Like Becket of Canterbury, St William of York was (allegedly) murdered in his cathedral - during a High Mass on May 30, 1154. One of his archdeacons was accused of poisoning his communion chalice, but the trial was apparently inconclusive. From 1177, miracles began to be attributed to him. When sweet smelling oil was rumoured to be seeping from his tomb in $1223,{ }^{5}$ local people were convinced he was a saint. Miracles were reported following his death, and his cult became very popular in northern England in the 14th and 15th centuries. William was officially canonised in 1227, exactly 600 years after the first Minster was built. This coincided with Walter de Grey starting the building of the south transept, and in the words of some of the cynics, "what better way to celebrate the 600th anniversary and finance a new building campaign by telling everybody that we've got our own saint now". Arguably, William was canonised at a time when it was highly convenient for the Minster to have a saint to encourage pilgrimages. One of the most famous pilgrims, Margery Kempe, describes her pilgrimage to York Minster to "make an offering at the shrine of St William" (Bale 2015: 111). However, Katja Boertjes (2007: 58) points out that Kempe was one of the few pilgrims who left a record of a visit to William's shrine and that this lack of written sources about pilgrimage to York is because most visitors would have come from surrounding areas.

William had a series of different shrines in the Minster, which became more elaborate over time, and thousands of pilgrims would have worshipped at the shrines before they were destroyed at the Reformation. The shrine of St William was restored when his body was rediscovered during excavations in the 1960s. On St William's day on June 8, services are held in the western crypt, which is an ecumenical space. ${ }^{6}$ The crypt is also used for "Candles and the Crypt" events with school groups. As a learning officer at York Minster put it to us:

With RE [Religious Education] groups we almost always finish in the Crypt anyway and we light candles down there, including the candles round the tomb, and put the lights out. But in most cases I don't talk about William, we have them at the other end, at the altar end, and we all have our own way of talking about the significance of light - I often base it on the Constantine story, actually, given that the remains of the military Governor's house are two and a half metres below that altar where Constantine Chlorus probably died or possibly died. But I don't find William sufficiently inspiring to draw this sort of spirituality out of it. Which is a shame. I mean, when you think that the north-east of England is so rich with fantastic saints like Cuthbert and Aidan and Wilfrid, and so on, and Oswald and we can't do that with William. I might be maligning the poor fellow - he might be a 
much better person. [...] It's unfortunate that St William is such an utterly boring saint, compared with Becket or even Mary at Walsingham. He's an early medieval career cleric who may or may not have been murdered by his colleagues which is interesting, it tells us quite a lot about the state of the church in the 12th century, but the best that you can say about him is that he was a fairly patient soul who didn't make too much of a fuss when he wasn't given the job first time round [...] but it doesn't exactly inspire, for me, it does not particularly inspire spiritual admiration. (Interview: July 14, 2015)

Comparing William unfavourably to other more famous saints is not uncommon. I was often told that William was "never a Cuthbert, or a John, or a Becket." For example, in the following quote a volunteer guide describes her enthusiasm for William, yet concedes that Cuthbert is a "far greater saint":

Oh I never stop talking about him [William]! [...] I also found out, only a few months ago, that St William was separated from his head as well, so the biggest part of him is in what is now the crypt. [...] But they put his head in another casket, so they could on St William's day walk him around York, and everybody thought they were getting the whole of St William, but it was only his head. But that was another guide that was telling us that, it probably is true but I had not heard that before. [...] I also compare the windows between St Cuthbert's window and the William window, and I also say that St Cuthbert was a far greater saint than William was, because of all the good works that he did, but William belonged to York, so that is why he is downstairs. (Interview: November 8, 2016)

Nonetheless, I heard one of the Minster guides proudly point out that Thomas Becket was murdered in 1170, William was murdered in 1154, and that "we still have his bones". Even though the Minster guides do not usually mention William during the tour, some do point out the St William window in the North Quire aisle (made c. 1414), usually comparing it to the St Cuthbert window opposite and its Victorian renovations. The St William window was restored in 2007 and it looks as close as possible to what it would have looked like when it was first constructed. The window has 95 stained glass panels depicting the life and death of William and some of the miracles he performed. One panel depicts a group of people collecting the healing oil that is pouring out of William's tomb, known for its miraculous cures. People would have rubbed themselves with the oil or drunk it while in the church, others would have taken the oil home in ampullae (Boertjes 2007: 49).

The fact that William of York was a local saint is rather significant. According to a staff member, "William is, although I wouldn't say he was particularly saintly, he is our saint and was a focus of medieval pilgrimage. [...] He was very very local." (Interview: July 15, 2015)

William, who seems to have been a "mild-mannered and probably cautious man" with the "knack of being at the right place at the right time and of meeting the people who mattered" (Norton 2006: 3), has been described by some as the "saint of the underdogs". He is also sometimes humorously called "a saint who never made it to the Premier League of saints" (FM: 2014-2015). 
During my fieldwork in York Minster I would spend a lot of time near St William's tomb in the crypt. In February 2015 I heard two visitors talking about a baby who was surreptitiously buried in William's tomb in the 17th century. I checked with Jenkins and he told me that one particularly poignant, if little-known, aspect of William's story is that the excavation of 1966-1973, which revealed his body for the first time since the 17th century, discovered a stillborn or new-born child had been placed in the coffin. Unbaptised and stillborn children could not be buried in consecrated ground, so by secretly placing him in the coffin before it was reburied, it seems that a 17th century parent was ensuring the best possible burial for their infant child.

When talking about the Crypt, several people have noted that it feels more like a museum than a spiritual place. A visitor commented:

I found in the crypt here, it was more museum-like, because when we walked around, the statues and ornamentations tended to be like exhibits in a museum. [...] But there was nowhere, even when we went to see the tomb of William, again, even though it is set out so you could pray and devote some of your spiritual attention to the tomb, it was still museum-like, exhibition-like, an exhibit-like sarcophagus. [...] I didn't get the spiritual feeling of being in a place of great sanctity or special sanctity at least. (Interview: December 2014)

In recent years there have been talks in the Minster about elevating William's tomb from the crypt to the main body of the cathedral. There are plans to reorder the high altar and bring it back to where it would have been when William's shrine would have been in place. A Cathedral canon stated the motivation behind this idea:

I think, obviously if we were to do that, it would give a much sharper focus to the kind of journey through the Minster. At the moment - when I first arrived and I think a lot of people share this - it is not immediately clear where is it all leading to, what's the heart of the Minster, and there is a sense in which the Undercroft, you could argue, is the heart, that's where William is, but we haven't got the narrative. The narrative is ambiguous and it's not, in one sense that location isn't the right location. If you think of St Cuthbert in Durham, or Alban in St Albans behind the high altar, it is the sort of obvious place, and I think if we were to do that, if that all came about, there would be a very different feel for where's the heart of the Minster, where is it all leading to. It will still take you to the high altar but beyond the high altar, a shrine. And I have no doubt that would change people's experience and possibly the reason for their coming. (Interview: July 29, 2015)

However, this idea is still very embryonic. It is probable that William's profile would be raised if his tomb was elevated to the main body of the Cathedral. This happened a lot in the Middle Ages; some medieval historians have pointed out that many medieval saints became famous after translation. Some people would argue that William of York received prominence for political reasons; now in a way he is receiving prominence again. Some scholars have suggested that in terms of the cults of saints there is always that element of luck, or popularity, so that some devotions take off and some do not, some devotions last, some do not. Since August 2016 there has been a candle stand for tea lights next to William's tomb; the plaque with his name and dates was put back in summer 2018, together with a couple of chairs where people can sit and contemplate. 
The placing of candle stands is important in the context of Anglican cathedrals, as lighting a candle directly in front of a tomb or statue may feel 'too Catholic' for some.

Here it is worth noting the rather intriguing co-existence of the 'high church' and 'low church' in the Church of England, which holds potential for tension and theological embarrassment. Coleman (2018: 29) has discussed a post-Reformation worry over the worship of objects. Coleman and Bowman (2018: 19) have posed the question, "To what extent could a post-Reformation Church appropriate the history and some of the materiality of its pre-Reformation spaces?" Having a so-called 'creepingly Catholic' (term used by one of our informants) dean and chapter who want to do high Anglican stuff with bones and tombs may bring out and reinforce the Protestant credentials of some. This is what a visitor to York Minster said on hearing about the clergy's plan to elevate St William's tomb: "Catholicism is creeping up from the crypt to the main body of the cathedral." (FM: July 2015) This sentiment is echoed by some who still associate saints and pilgrimage with Catholicism and find their re-emergence in the Church of England difficult to come to terms with. A volunteer guide expressed the lack of enthusiasm among some of the 'low church' people about things that used to be associated with Catholicism:

I am old-fashioned Church of England. In my younger days we didn't have pilgrimages, the word didn't exist really in our sort of world. Bishops and archbishops and all the rest of it didn't do this sort of thing in the days when I was brought up. (Interview: December 9, 2015)

The conflict between the high and low church is illustrated by the famous belief in York that if the Minster does not have any scaffolding on it, you have to "give it back to the Catholics". Just before the Millennium of 2000, this belief led to a big controversy over removing the scaffolding, with many people phoning in expressing their concern that when all the scaffolding is removed the place would become Catholic. Similarly, in Canterbury I was told about a Catholic lady who, when talking about the Cathedral, said "Oh we have only lent you this..." (FM: August 2015)

Back to the saints: while Becket and Cuthbert still draw people to Canterbury and Durham, William of York is far less known.

\section{THE EFFECT OF SAINTS ON THE PILGRIMAGE CULTURE OF CATHEDRALS TODAY ${ }^{7}$}

If we are to approach the heart of pilgrimage, let us borrow the clothes of medieval men and women, feel the hardness of the roads under their bare penitential feet, and above all see the shrines in those cool dim cathedrals through their thankful eyes (Adair 1978: 7).

Modern pilgrims often try to emulate the medieval pilgrim who is seen as the ideal, "authentic" pilgrim (Frey 1998; Sepp 2012; 2014). Canterbury Cathedral, Durham Cathedral and York Minster were all major medieval pilgrim destinations. In traditionally Protestant England, medieval Anglican cathedrals, with a history of pilgrimage that was totally disrupted by the Reformation, are now encountering new forms of 
pilgrimage; often coloured by Caminoisation (Bowman and Sepp 2018). Pilgrimage is being rediscovered and reframed not only in England but also in several other European countries, including areas where pilgrimage was long discredited and discontinued for both theological and ideological reasons. Coleman and Bowman (2018: 30) point out that as a complex and multi-layered practice, pilgrimage touches on many points of uncertainty for Anglican cathedrals, for example, there is the question of how and whether a post-Reformation institution should be encouraging such activity, and, more generally, how far the Church of England can reappropriate medieval practices of piety.

Pilgrimage to, within and from Canterbury Cathedral forms an organic part of the life of the Cathedral and is part of a wider pilgrimage network (Bowman and Sepp 2018: 14). Even though the shrine and remains of Becket are long gone, his martyrdom continues to be the main focus at Canterbury. His story lives on in the guided tours, numerous publications, exhibitions, and so on. At the same time, Canterbury Cathedral continues to have a very lively pilgrimage scene - many people go there as self-identified pilgrims; many foot pilgrims are blessed on arriving (usually from Winchester, also from London and Dover) or departing for pilgrimage (mainly to Rome or Santiago de Compostela). The lively and ambiguous pilgrim culture of Canterbury Cathedral is at least partially fuelled by people who have walked the Camino. One of the Canterbury pilgrims said this about Becket: "I was always aware of his courage and faith but the pilgrimage brought it into sharper focus, particularly seeing where he was murdered". (Interview: October 24, 2016)

Durham Cathedral, which for many people remains centred on the powerful story of St Cuthbert, also welcomes big numbers of pilgrims every year. These can be foot pilgrims, bicycle pilgrims, but also people working at the Cathedral. A volunteer guide told us: "I go on pilgrimage to Cuthbert's shrine, and I suppose in a way I do it every day, because every time I come in, I go to the shrine and I light a candle" (interview: May 25, 2015). When interviewing the staff and volunteers of Durham Cathedral, many of them would say that it is Cuthbert that people come on pilgrimage to. I will quote one of the canons:

From the founding of the Cathedral in the year 995, when Cuthbert's body came, people have come on pilgrimage because Cuthbert is held in great esteem, and pilgrimage is a way in which people deliberately associate themselves with that which they respect, honour. [...] Most particularly I would say that Cuthbert is the centre of our pilgrimage. (Interview: May 28, 2015)

For instance, there is a waymarked pilgrimage route from the parish church of Witton Gilbert - which belongs to the Small Pilgrim Places network - to Durham Cathedral.

For many people, pilgrimage to and from Durham is associated with the Holy Island of Lindisfarne. Several pilgrims told us about their experiences of the Methodist Women in Britain pilgrimage from Durham to Lindisfarne. The organiser told us that "each pilgrimage starts at the shrine of St. Cuthbert at 3pm, when we begin by joining prayers led there by the Cathedral staff - a perfect start for us!" (Interview: April 12, 2016) As one of the Lindisfarne pilgrims put it to us, "He [Cuthbert] was such a holy man who was instrumental in spreading the word of God throughout our region and country: he led the way for us pilgrims to follow and set an example for us" (interview: April 13, 
2016). In the words of another pilgrim, "knowing we were walking in the footsteps of saints, especially St Cuthbert was very significant. [...] I felt that St Cuthbert and his fellow pilgrims were sharing in our experience." (Interview: April 18, 2016)

Another example of pilgrimage to Durham is the tradition of St Cuthbert's Day Walk. Since 2006, the Northumbrian Association has held its annual walk which starts from St Mary's and St Cuthbert's Church in Chester-Le-Street and arrives at Durham Cathedral via the Market Place. The St Cuthbert Banner is brought from the Cathedral and carried in a civic procession from the Market Place to the Cathedral. The banner and the walkers are then welcomed to the Cathedral for a procession and prayers at the shrine of St Cuthbert. Pilgrimages within Durham Cathedral usually finish in Cuthbert Feretory; however, when a bigger group is split in two, then one guide starts at east and the other at west.

Interestingly, even though St Cuthbert was an Anglo-Saxon saint, his popularity can to a considerable extent be related to the growth of interest in 'Celtic spirituality' (see Bowman 2000). As a volunteer guide put it, "It's the growth of interest in the northern saints and the so-called Celtic spirituality, that's what's caused the growth [in pilgrimage] here I think. And it really has grown." (Interview: May 25, 2015) Several people go on 'Celtic pilgrimage' to Durham Cathedral and are then told that their saints are Anglo-Saxon, not Celtic (the only Celtic saint they have is Aidan).

Pilgrimage at and within York Minster is virtually non-existent even though they still have a resident saint - St William of York. The story of William just does not seem to draw in pilgrims. However, the new exhibition Tourist, Traveller, Pilgrim? which opened in the Minster's Treasury area in 2017 is drawing attention to William.

Many people, including self-identified pilgrims, are drawn to the cathedrals because "those walls have heard so many prayers". However, I contend that equally significant factors in the formation and shaping of the contemporary pilgrimage landscape in our case study cathedrals are the drawing power of medieval saints and the stories about them. If pilgrimage is about the story one is following, then analysis of the formation and development of stories about the saints is illuminating. I suppose it is fair to describe the role of saint's narratives in shaping the contemporary pilgrim culture as highly significant.

\section{LOOKING FOR A MASTER NARRATIVE}

The canon quoted in the title of this article was referring to the 'ambiguous narrative' and not exactly ideal location of the tomb of St William of York. Similar concerns have been expressed by some other staff members; in fact, one of the main things that emerged from our interviews with the Minster staff and volunteers was that they had been looking for a 'metanarrative'. Unlike Durham Cathedral who have St Cuthbert and Canterbury who have St Thomas Becket, York Minster lacks one clear central narrative. Tour guides tell the Edwin and Ethelburga story and mention the Constantine connection (Constantine was proclaimed emperor in York in AD 306), they elaborate on the Minster fires. St William of York, however, does not get much of a mention. We were told that what is lacking is the metanarrative (whether this is a downside or an opportunity is up for discussion). 
With regard to the focus, York Minster seems to have several of them. York Minster fires, in particular, capture the imagination of many guides and visitors. Legends about the fires are vividly told by tour guides and published in guidebooks and various other publications and thus play a significant role in the presentation of the cathedral. The question "What really caused the fire?" can lead to fascinating debates. As an aside, there is a parallel here with Canterbury Cathedral, where the question about what really happened to the bones of Thomas Becket has intrigued people for centuries. York Minster fires and their official and unofficial causes are one of the central themes of the Minster's guided tours. This is probably partly because it gives the guides a good opportunity to talk about different styles of architecture and new features that were added after the fires, but also because it seems to be a good way of presenting and testing various vernacular theories. For example, you may be told that the intricate wooden carvings around the Quire area are a copy of the medieval original and that this is due to one man - a religious maniac Jonathan Martin, who in 1840 started the fire because he did not like organ music. And a most dramatic story will follow, with each guide focussing on their favourite details, such as showing where Martin had hidden himself during the night or suggesting various explanations for his arson. Some say that Martin did not like either the Church of England or the Minster, and particularly disliked the organ - because he heard it say offensive things about himself. The other major conflagration that guides always talk about is the 1984 one, which started in the early hours of July 9 and destroyed the roof of the south transept. The cause of the fire was never conclusively proven; the most likely cause being a bolt of lightning. Some people attribute the fire to "divine retribution", and mention the name of Reverend David Jenkins, the then Bishop of Durham, who was consecrated in York Minster. Apparently the bishop had said offensive things about church and religion - he had questioned the literal truth of the virgin birth or miracles such as Jesus walking on water - and that was why the Almighty had decided to teach a lesson. The fire started three days after the bishop's consecration, so for some people it was the wrath of God. However, one of the tour guides noted that "if it really had been the Almighty, he would have got a better shot".

In contrast to Canterbury and Durham, while doing fieldwork in York I often felt I was inundated with all kind of narratives. I argue that the multiplicity of stories circulating in York Minster is a direct consequence of the lack of a core narrative. This void seems to have led to an abundance of stories; the ground of York Minster certainly feels very fertile from the folkloristic perspective. In Canterbury and Durham their respective saints' narratives are so dominant that quite simply there is not much space left for other stories; York, however, is a very 'storied' place and there seem to be fewer restrictions on the guides' repertoire. I suppose York can probably afford to be more playful and less inhibited than Canterbury Cathedral, which, as the Mother Church of the Worldwide Anglican Communion, is understandably more restricted and regulated on all levels. For example, they did not allow the filming of Harry Potter in their cathedral. As a member of staff put it to us:

So if we are asked, can we film Harry Potter here, the answer is, no you can't. He has nothing to do with us as a community and because of the witchcraft element, the magic that's part of it. Magic to African churches and witchcraft and all those things is still quite a big issue, and as the Mother Church of the Anglican World- 
wide Communion, we have various dioceses which have African churches, and so for them to see the Mother Church has been part of some strange fictional story which involves witchcraft would seem to be slightly odd. (Interview: August 12, 2015)

To give another example, three years ago, news about York Minster "quietly bringing in Zen Buddhism" hit the headlines in the UK. ${ }^{8}$ For the last few years, there have been weekly Zen sits in the Old Palace, led by the 'religiously bilingual' canon of York Minster. Again, it is hard to imagine this happening in Canterbury.

Here it is appropriate to compare the book sections of the gift shops of Canterbury Cathedral and York Minster. Every time I have been to Canterbury Cathedral bookshop looking for a book about contemporary stories I have not been able to find anything. The shop assistants told me that "sadly all the books that we have are about history". I suggest this is probably because in Canterbury they are completely happy with the history and therefore do not need to create/publish new stories. York Minster is exactly the opposite: their book section is full of books about various contemporary stories and legends, for example The Minster Tales, York Minster Fires, and so on. In 2018, another fascinating book was published, co-authored by three former Minster staff, entitled Not Just a Job: Stories from York Minster (Key et al. 2018).

I suppose we should also consider the fact that unlike Canterbury and Durham, York is considered one of the most haunted - if not the most haunted - cities in the UK. Visitors to the city can choose from a wide range of ghost tours; it is easy to find books with titles such as Haunted York. Naturally some of the city's ghost stories would spill into the Minster. Several people we talked to said that the Minster can feel a bit spooky, particularly at night. In July 2016 some members of our team spent a couple of hours in the Minster late at night; we also interviewed the Minster Police officer who was on duty that night. She said:

It is different at night... [...] When I first started, there was loads of stories that people tell about seeing people and figures and shadows, a lot of this is I think, this is the new person, let's see... [They said] that they'd seen people, figures, walking through walls. That they had heard people laughing, people crying, people shouting, lots of loud bangs coming from left, right and centre. All sorts of things, but when you are the new person you take it all with the pinch of salt, don't you? And yes, there've been nights when it's been really really noisy in there, but it's usually because it's windy. And we have got obviously all the doors high level on the inside, that a lot of them don't shut properly, some don't shut at all, some just rattle away, and of course the wind just whistles around the top anyway. So it's always going to be a noisy place, and of course it creaks and groans and expands and everything normal but yes... [...] It is different when it is $3 \mathrm{o}^{\prime}$ clock in the morning and you are tired and you are thinking I don't really know what that is! (Interview: August 2, 2016)

We have also interviewed a former Minster policeman, who is now a volunteer guide at the Minster. He said, "Lots of people say to me, is it spooky, did you have experiences, did you see things. Ghosts are always on people's mind." (Interview: December 9, 2015) 
English folklore and literature are rich in references to ghosts, and a high proportion of the English believe they exist (Simpson 2008: 25). The term 'ghost' can mean and imply many different things, and narratives about ghosts can be either personal or communal (ibid.) Paul Cowdell's (2011) research found a broad social spread of ghost belief. He notes that ghosts are a stubborn presence in British culture, and they "remain ingrained in our culture and language" (ibid.: 1). Valk (2012: 184) has described how the linking of personal experience narratives with collective tradition renders them believable. He comments, "If memorates include elements of shared beliefs, even strange and untraditional episodes become meaningful and comprehensible" (ibid.).

In December 2015 I had a chat about ghosts with one of the Minster guides who had previously worked in the Treasurer's House. He told me that the Treasurer's House was haunted - he had heard several stories about the Grey Lady, who used to reside in Theatre Royal, but when that was closed for restauration works, had moved to the Treasurer's House. In Theatre Royal she would only appear when somebody was on their own, never when there was more than one person present. I asked the guide if there were any ghosts in the Minster. He said no, and explained that this was because ghosts only appeared when the dead were unhappy. He added that everybody who had been buried in the Minster was happy.

\section{CONCLUSION}

In this article I have tried to "observe and capture the flow of vernacular discourse and reflect on it" as Bowman and Valk (2012: 2) suggest in the introduction to their book Vernacular Religion in Everyday Life. I have attempted to give some insights into how cathedral workers as well as visitors view the saints and their shrines in the post postReformation England. The Church of England's relatively recent tendency towards shrines has brought with it the need to devise new strategies of presenting them, which for various reasons can be rather complicated. This conflict is humorously summarised by one of our informants who speaks about

the tension between clergy who are drawn to cathedrals because they really like dressing up and therefore tend to come from the very sort of Anglo-Catholic end and clergy who are drawn to cathedrals because they see them as wellsprings of mission and therefore tend to be from the much lower end of the church. (Interview: August 2, 2016)

I have attempted to cover some of the most salient points in relation to the presentation and interpretation of medieval saints today in Canterbury, Durham and York. Briefly, my main arguments have been the following.

Firstly, the location and accessibility of a saint's tomb or shrine continue to play a significant role in their popularity. For example, William of York might get more visitors and worshippers if his tomb was not tucked away in the crypt; the Venerable Bede's tomb might be as popular as Cuthbert's if it was not in a too open, yet peripheral public area. Several scholars, for example Bonna D. Wescoat and Robert G. Ousterhout (2012: xxi), have emphasised the "connection between architecture as a creator and signifier of sacred space and the actions that concretised religious belief". 
Secondly, many people go to the cathedral looking for answers to do with death. That is probably also connected to relics - people are very interested in the shrines and tombs. The murder mysteries add to the religious as well as non-religious experience of the place. Becket's famous martyrdom makes Canterbury Cathedral very attractive for both religious and historical/cultural reasons.

Thirdly, given that one of our team's research questions was what model of pilgrimage (if any) our case study cathedrals were presenting, I have pointed out that there seems to be a correlation between pilgrimage activities and the popularity of the cathedral's saint. Even though several people told us that the remains of a saint are irrelevant and what really matters to them is that for hundreds of years people have made a pilgrimage to these holy places, one cannot help noticing that pilgrimage forms an organic part of the life of Canterbury and Durham, who also have very popular saints. Canterbury is a destination for those who travel along the pilgrim paths from Winchester and other places; it is also the beginning of the route to Santiago de Compostela in Spain and the Via Francigena to Rome. Durham Cathedral has always been dominated by the presence of St Cuthbert. Pilgrimage within and to Durham Cathedral is predominantly about St Cuthbert, who continues to draw in significant numbers of people. There is, however, virtually no pilgrimage to York Minster, which may reflect the extent of popularity of their resident saint, St William of York.

Fourthly, I have approached the stories, legends and rumours about medieval saints as interpretations and negotiations of the concept and characters of saints, their role and relevance, shaping the perception of the cathedrals. These stories are expressions as well as shapers of vernacular religion. Canterbury and Durham cathedrals have clear master narratives around their respective saints Thomas Becket and St Cuthbert and to some extent the Venerable Bede. There are, however, obvious 'deviations' from these central narratives when people express contradicting beliefs. Significantly, as Valk (2012: 366) comments,

In contrast to institutionally established discourses with monological voicing the expressive field of folklore is always heteroglot. Dominant discourses, with claims to hegemonic authority and expressing ultimate truths, generate counter arguments, become targets of attacks and are refuted. Legends are thus transformed into anti-legends, vernacular theories that are built up are at the same time critically analysed and torn to pieces by the weavers of the same discursive web.

In contrast to Becket and Cuthbert, William of York simply does not seem to capture people's imagination in the same way, leaving a vacancy, an empty space for other stories to abound. This is marvellous, certainly from the folkloristic perspective. Watching the process of searching for a master narrative in York Minster one might wonder whether adopting a sort of 'top down' approach is likely to work. I will quote someone who has been working for the Minster for many years:

If I walk outside and walk round with friends I just look at the scale of the place and think, how on earth can anybody be in control of that place? Because it's too big. One of the things I've always said to colleagues is - the Minster is bigger than any individual, and there are individuals who've thought they were bigger than the place and they are the ones who fall flat on their faces, because there is no way 
you can fight against this vast space, you've just got to go with it. It has got its own sort of dynamic, and anyone who tries to fight against it is actually quite foolish because you are not going to win. I know that from my 25 years of experience that you just have to go with it. (Interview: February 10, 2015)

Finally, for many people, visits and pilgrimages to the cathedral are more about prayer and reflection and connecting with the cathedral rather than with the saint. In order not to be overwhelmed by the size and complexity of the cathedral, people need a focus. For a considerable number of people - notwithstanding their religious background - who need a focus in the rather complex space of a cathedral, a saint could be that focus. As we do not have enough evidence for this yet, I would like to provide the following as a hypothesis for further testing: Could a saint be the focus we need in the rather confused and confusing space of the cathedral?

\section{NOTES}

1 For Becket's biography, see, for example, Guy 2012.

2 For lighting candles as an increasingly common feature of Anglican cathedrals, see Coleman and Bowman 2018: 27-28.

3 The shrine prayers take place from Monday to Saturday at 11:15 and 15:00. At the end of those prayers people are invited to light a candle and put it on St Cuthbert's tomb.

4 A former Minster worker told us: "So flowers have always been a little bit, you know. I mean, it took three chapter meetings to get agreement that flower arrangers could put a small flower arrangement on William's tomb on St William's Day, a small flower arrangement, because otherwise it's all a bit slippery." (Interview: August 2, 2016)

5 Duffy (forthcoming) notes that the sudden miraculous flow of sweet-scented oil from William's tomb looks like a direct riposte by the mother-church of the northern province to the spectacular translation of Becket's body to a new shrine in 1220. See also Norton 2006: 161-162.

6 The square altar at the shrine is a gift from the Roman Catholics in the diocese of Leeds.

7 For a more detailed overview of contemporary pilgrimage to and within our case study cathedrals, see Bowman and Sepp 2018. Our article sets out to establish if and how the attraction and authority of the Santiago pilgrimage reflect in the pilgrim culture of English cathedrals. We argue that the latest reframing of pilgrimage in English cathedrals owes much to Caminoisation.

8 Bingham 2016.

\section{SOURCES}

FM = Fieldwork materials (in the form of field notes) of the author. Materials are kept in the author's personal collection.

Interviews quoted in the article belong to the Pilgrimage and England's Cathedrals, Past and Present project. Conducting interviews was carried out by Marion Bowman, Simon Coleman and Tiina Sepp. 


\section{REFERENCES}

Adair, John Eric. 1978. The Pilgrims' Way: Shrines and Saints in Britain and Ireland. London: Thames and Hudson.

Bale, Anthony, ed. 2015. The Book of Margery Kempe. Oxford World's Classics. Oxford: Oxford University Press.

Bartlett, Robert. 2013. Why Can the Dead Do Such Great Things? Saints and Worshippers from the Martyrs to the Reformation. Princeton, NJ; Oxford: Princeton University Press. DOI: https://doi. org/10.1515/9781400848782.

Bede (= Beda Venerabilis). 2013 [1939]. Life of St Cuthbert. Two Lives of Saint Cuthbert: A Life by an Anonymous Monk of Lindisfarne and Bede's Prose Life, translated and commented by Bertram Colgrave. Milton Keynes: Lightning Source UK Ltd.

Bede (= Beda Venerabilis). 1930 [731]. Historia Ecclesiastica Gentis Anglorum. The Ecclesiastical History of the English Nation. London: Dent.

Bingham, John. 2016. York Minster Brings in Zen Buddhism, Quietly. - The Telegraph. https:// www.telegraph.co.uk/news/2016/05/15/york-minster-brings-in-zen-buddhism-quietly/ (accessed May 13, 2019).

Boertjes, Katja. 2007. Pilgrim Ampullae of York Minster and the Healing Oil from the Shrine of St William. - Beyond Pilgrim Souvenirs and Secular Badges: Essays in Honour of Brian Spencer, edited by Sarah Blick. Oxford; Oakville, CT: Oxbow Books; David Brown Book Co., 48-63.

Bowman, Marion. 2000. Contemporary Celtic Spirituality. - New Directions in Celtic Studies, edited by Amy Hale and Philip Payton. Exeter: Exeter University Press, 69-91.

Bowman, Marion and Ülo Valk. 2012. Introduction: Vernacular Religion, Generic Expressions and the Dynamics of Belief. - Vernacular Religion in Everyday Life: Expressions of Belief, edited by Marion Bowman and Ülo Valk. Sheffield; Bristol, CT: Equinox Publishing, 1-19.

Bowman, Marion and Tiina Sepp. 2018. Caminoisation and Cathedrals: Replication, the Heritagisation of Religion, and the Spiritualisation of Heritage. - Religion (Thematic Issue: Religion in Cathedrals: Pilgrimage, Place, Heritage, and the Politics of Replication) 49 (1): 74-98. DOI: https:// doi.org/10.1080/0048721X.2018.1515325.

Bowman, Marion; Simon Coleman, John Jenkins and Tiina Sepp. 2018. Visibly Different: Continuity and Change at Westminster Cathedral. - The Desecularisation of the City: London's Churches, 1980 to the Present, edited by David Goodhew and Anthony-Paul Cooper. London; New York, NY: Routledge, 300-327.

Butler, John. 1995. The Quest for Becket's Bones: The Mystery of the Relics of St Thomas Becket of Canterbury. New Haven, CT; London: Yale University Press.

Chaucer, Geoffrey. 1998 [1392]. The Canterbury Tales. London: The Folio Society.

Coleman, Simon. 2009. Mary on the Margins? The Modulation of Marian Imagery in Place, Memory, and Performance. - Moved by Mary: The Power of Pilgrimage in the Modern World, edited by Anna-Karina Hermkens, Willy Jansen and Catrien Notermans. Farnham: Ashgate, 17-32.

Coleman, Simon. 2018. On Praying in an Old Country: Ritual, Replication, Heritage, and Powers of Adjacency in English Cathedrals. - Religion (Thematic Issue: Religion in Cathedrals: Pilgrimage, Place, Heritage, and the Politics of Replication) 49 (1): 120-141. DOI: https://doi.org/10.1080/ 0048721X.2018.1515326.

Coleman, Simon; Marion Bowman and Tiina Sepp. 2019. A Cathedral is Not Just for Christmas: Civic Christianity in the Multi-Cultural City. - The Public Work of Christmas: Difference and Belonging in Multicultural Societies, edited by Pamela E. Klassen and Monique Scheer. 302-330.

Coleman, Simon and Marion Bowman. 2018. Religion in Cathedrals: Pilgrimage, Heritage, Adjacency, and the Politics of Replication in Northern Europe. - Religion (Thematic Issue: Religion in Cathedrals: Pilgrimage, Place, Heritage, and the Politics of Replication) 49 (1): 1-23. DOI: https:// doi.org/10.1080/0048721X.2018.1515341. 
Cowdell, Paul. 2011. Belief in Ghosts in Post-War England. Doctoral thesis. https://www.academia.edu/26832584/Belief_in_Ghosts_in_Post-War_England (accessed May 15, 2019).

Curtis, Simon. 2016. English Cathedrals: Events and Spiritual Capital. - International Journal of Religious Tourism and Pilgrimage 4 (2): 1-11.

Davie, Grace. 2012. A Short Afterword: Thinking Spatially About Religion. - Culture and Religion 13 (4): 485-489. DOI: https://doi.org/10.1080/14755610.2012.728387.

Dégh, Linda. 2001. Legend and Belief: Dialectics of a Folklore Genre. Bloomington, IN; Indianapolis, IN: Indiana University Press.

Dubisch, Jill. 1995. In a Different Place: Pilgrimage, Gender, and Politics at a Greek Island Shrine. Princeton, NJ: Princeton University Press. DOI: https://doi.org/10.1515/9781400884414.

Duggan, Anne. 2004. Thomas Becket. London: Arnold.

Duffy, Eamon. 2002. Saints \& Sinners: A History of the Popes. New Haven, CT; London: Yale Nota Bene; Yale University Press.

Duffy, Eamon. 2004. Faith of Our Fathers: Reflections on Catholic Tradition. London, New York, NY: Continuum.

Duffy, Eamon. Forthcoming. Cathedral Pilgrimage: The Later Middle Ages.

Durant, Will. 1957. The Reformation: A History of European Civilization from Wyclif to Calvin: 13001564. The Story of Civilization 6. New York, NY: MJB Books.

Eade, John and Michael J. Sallnow. 2000 [1991]. Contesting the Sacred: The Anthropology of Christian Pilgrimage. Urbana, MD; Chicago, IL: University of Illinois Press.

Eco, Umberto. 1986. Travels in Hyperreality: Essays. San Diego, CA: Harcourt Brace \& Co.

Eliot, Thomas Stearns. 1952. Murder in the Cathedral. London: Faber and Faber Ltd.

Ferreiro, Alberto. 2000. The Cult of Saints and Divine Patronage in Gallaecia before Santiago. - The Pilgrimage to Compostela in the Middle Ages, edited by Maryjane Dunn and Linda Kay Davidson. New York, NY; London: Routledge, 3-22.

Frey, Nancy Louise. 1998. Pilgrim Stories: On and Off the Road to Santiago. Journeys Along an Ancient Way in Modern Spain. Berkeley, CA: University of California Press.

Groves, Lilian. 2008. A Glimpse of Our Monastic Past Based on the Rites of Durham. Durham: The Chapter of Durham Cathedral; Jarrold Publishing.

Guy, John. 2012. Thomas Becket. London: Viking.

Jenkins, John. 2018. Replication or Rivalry? The 'Becketization' of Pilgrimage in English Cathedrals. - Religion (Thematic Issue: Religion in Cathedrals: Pilgrimage, Place, Heritage, and the Politics of Replication) 49 (1): 24-47. DOI: https://doi.org/10.1080/0048721X.2018.1515327.

Jenkins, John and Alana Harris. 2018. More English than the English, more Roman than Rome? Historical Signifiers and Cultural Memory at Westminster Cathedral. - Religion (Thematic Issue: Religion in Cathedrals: Pilgrimage, Place, Heritage, and the Politics of Replication) 49 (1): 48-73. DOI: https://doi.org/10.1080/0048721X.2018.1515328.

Jones, Graham. 2007. Saints in the Landscape. Chalford: Tempus Publishing.

Key, John; Richard Bunday and Roy Pawsey. 2018. Not Just a Job: Stories from York Minster. York: York Against Cancer.

Lang-Sims, Lois. 1979. Canterbury Cathedral: Mother Church of Holy Trinity. London: Cassell.

Katajala-Peltomaa, Sari; Kirsi Salonen and Kurt Villads Jensen. 2016. In the Name of Saints Peter and Paul: Popes, Conversion, and Sainthood in Western Christianity. - Church and Belief in the Middle Ages: Popes, Saints and Crusaders, edited by Kirsi Salonen and Sari Katajala-Peltomaa. Amsterdam: Amsterdam University Press, 11-35. DOI: https://doi.org/10.1515/9789048525720002.

Norton, Christopher. 2006. St William of York. York: York Medieval press.

Oring, Elliott. 2008. Legendry and the Rhetoric of Truth. - Journal of American Folklore 121 (480): 127-166. DOI: https://doi.org/10.1353/jaf.0.0008. 
Pilgrimage and England's Cathedrals = About the project. - Pilgrimage and England's Cathedrals: Past and Present. http://www.pilgrimageandcathedrals.ac.uk/about (accessed May 13, 2019).

Primiano, Leonard Norman. 1995. Vernacular Religion and the Search for Method in Religious Folklife. - Western Folklore (Special Issue: Reflexivity and the Study of Belief) 54 (1): 37-56. DOI: https://doi.org/10.2307/1499910.

Primiano, Leonard Norman. 2012. Manifestations of the Religious Vernacular: Ambiguity, Power, and Creativity. - Vernacular Religion in Everyday Life: Expressions of Belief, edited by Marion Bowman and Ülo Valk. Sheffield; Bristol, CT: Equinox Publishing, 382-394.

Sánchez Dragó, Fernando. 2004. Historia magica del Camino de Santiago. Barcelona: Editorial Planeta.

Sepp, Tiina. 2012. Stories of Santiago Pilgrims: Tradition through Creativity. - Vernacular Religion in Everyday Life: Expressions of Belief, edited by Marion Bowman and Ülo Valk. Sheffield; Bristol, CT: Equinox Publishing, 301-327.

Sepp, Tiina. 2014. Pilgrimage and Pilgrim Hierarchies in Vernacular Discourse: Comparative Notes from the Camino de Santiago and Glastonbury. - Journal of Ethnology and Folkloristics 8 (1): 23-52. https://www.jef.ee/index.php/journal/article/view/129 (accessed May 13, 2019).

Simpson, Jacqueline. 2008. A Ghostly View of England's Past. - Legends and Landscapes, edited by Terry Gunnell. Reykjavik: University of Iceland Press, 25-38.

Tavinor, Michael. 2016. Shrines of the Saints in England and Wales. Norwich: Canterbury Press.

Valk, Ülo. 2012. Belief as Generic Practice and Vernacular Theory in Contemporary Estonia. - Vernacular Religion in Everyday Life: Expressions of Belief, edited by Marion Bowman and Ülo Valk. Sheffield; Bristol, CT: Equinox Publishing, 350-368.

Wescoat, Bonna D. and Robert G. Ousterhout. 2012. Preface. - Architecture of the Sacred: Space, Ritual, and Experience from Classical Greece to Byzantium, edited by Bonna D. Wescoat and Robert G. Ousterhout. Cambridge; New York, NY: Cambridge University Press, xxi-xxiv. DOI: https://doi.org/10.1017/CBO9781139017640. 